\title{
Metformin enhances the cytotoxicity of 5-aminolevulinic acid-mediated photodynamic therapy in vitro
}

\author{
TOMOHIRO OSAKI $^{1}$, INORU YOKOE ${ }^{1}$, KIWAMU TAKAHASHI $^{2}$, KATSUSHI INOUE $^{2}$, \\ MASAHIRO ISHIZUKA ${ }^{2}$, TOHRU TANAKA ${ }^{2}$, KAZUO AZUMA ${ }^{1}$, YUSUKE MURAHATA ${ }^{1}$, \\ TAKESHI TSUKA ${ }^{1}$, NORIHIKO ITOH ${ }^{1}$, TOMOHIRO IMAGAWA ${ }^{1}$ and YOSHIHARU OKAMOTO ${ }^{1}$ \\ ${ }^{1}$ Joint Department of Veterinary Clinical Medicine, Faculty of Agriculture, Tottori University, \\ Tottori 680-8553; ${ }^{2}$ SBI Pharmaceuticals Co., Ltd., Tokyo 106-6020, Japan
}

Received February 10, 2016; Accepted January 13, 2017

DOI: $10.3892 / 01.2017 .6237$

\begin{abstract}
The biguanide metformin is a drug widely used for the treatment of type 2 diabetes. Metformin enhances the cytotoxicity of chemotherapy by promoting the adenosine monophosphate-activated protein kinase (AMPK) autophagy signaling pathway. Photodynamic therapy (PDT) with 5-aminolevulinic acid (5-ALA), a precursor of protoporphyrin IX (PpIX), leads to apoptosis when PpIX accumulates in the mitochondria, and also leads to autophagy through activation of AMPK. In the present study, the effect of metformin in combination with 5-ALA-PDT was evaluated in vitro in KLN205 lung cancer cells. At a fluence of $5 \mathrm{~J} / \mathrm{cm}^{2}, 5$-ALA-PDT in combination with $5 \mathrm{mM}$ metformin exhibited significantly increased cytotoxicity compared with that observed with 0 and $0.1 \mathrm{mM}$ metformin $(\mathrm{P}=0.0197$ and $\mathrm{P}=0.0423$, respectively). The cells treated with 5-ALA-PDT and metformin exhibited condensation of nuclear chromatin and the presence of autophagosomes. These results indicate that apoptosis and autophagy occur in KLN205 cells following combined treatment with 5-ALA-PDT and metformin. The results from the present study are the first to indicate, to the best of our knowledge, that metformin potentiates the efficacy of 5-ALA-PDT.
\end{abstract}

Correspondence to: Professor Tomohiro Osaki, Joint Department of Veterinary Clinical Medicine, Faculty of Agriculture, Tottori University, 4-101 Koyama-cho Minami, Tottori 680-8553, Japan E-mail: tosaki@muses.tottori-u.ac.jp

Abbreviations: AMPK, adenosine monophosphate-activated protein kinase; 5-ALA, 5-aminolevulinic acid; mTOR, mammalian target of rapamycin; MAPK, mitogen-activated protein kinase; MDC, monodansylcadaverine; PDT, photodynamic therapy; PI, propidium iodide; PpIX, protoporphyrin IX

Keywords:5-aminolevulinic acid, apoptosis, autophagy, cytotoxicity, metformin, photodynamic therapy

\section{Introduction}

Photodynamic therapy (PDT) has been developed as an effective treatment for malignant tumors. PDT involves the administration of a photosensitizer, which preferentially accumulates in malignant tissue, and its subsequent activation by light of the appropriate wavelength $(1,2)$. The interaction of light with the intracellular photosensitizer causes the release of oxygen radicals, leading to cell death (3).

5-Aminolevulinic acid (5-ALA) is a precursor of protoporphyrin IX (PpIX), a well-known photosensitizer, and is converted in situ to PpIX via the heme biosynthetic pathway (4). 5-ALA has been used successfully for photodynamic diagnosis and PDT $(5,6)$. Although 5-ALA-PDT has been intensively studied for several decades, the mechanism underlying its cytotoxicity is not well known. It has been demonstrated that 5-ALA-PDT leads to apoptosis when PpIX accumulates in the mitochondria and to necrosis when it diffuses into the cytoplasm (7). A previous study reported that 5-ALA-PDT induced autophagic cell death through the activation of adenosine monophosphate-activated protein kinase (AMPK) (8).

The biguanide metformin (N,N-dimethylimidodicarbonimidic diamide), a widely used drug for the treatment of type 2 diabetes, reduces blood glucose levels by suppressing gluconeogenesis in the liver and increasing glucose uptake by the skeletal muscle $(9,10)$. Additionally, metformin has been demonstrated to significantly inhibit tumor growth in several types of cancer and mouse tumor models (11-13). It was reported that metformin can control the proliferation of cancer cells, and this effect was associated with a number of signaling pathways, including the activation of AMPK and mitogen-activated protein kinase (MAPK) signaling, and decreased mammalian target of rapamycin (mTOR) and epidermal growth factor signaling (14).

Several studies have identified that metformin enhances the cytotoxicity of chemotherapy by promoting the AMPK-autophagy pathway (15-18). In addition, metformin has been demonstrated to cause cell death in radiosensitized cancer cells and radioresistant cancer stem cells by activating AMPK and suppressing mTOR (19). These data provide the rationale to study the role of metformin in other cancer therapies. 
To the best of our knowledge, no prior studies investigating the effects of 5-ALA-PDT in combination with metformin have been reported. In the present study, the effect of metformin in combination with 5-ALA-PDT was evaluated in vitro in KLN205 lung cancer cells. The results indicate that metformin potentiates the efficacy of 5-ALA-PDT.

\section{Materials and methods}

Cell culture. KLN205 lung cancer cells were obtained from the Institute of Development, Aging and Cancer of Tohoku University (Sendai, Japan). KLN205 cells were maintained in RPMI-1640 medium (Invitrogen; Thermo Fisher Scientific, Inc., Waltham, MA, USA) supplemented with $10 \%$ heat-inactivated fetal bovine serum (FBS; Wako Pure Chemical Industries, Ltd., Osaka, Japan), penicillin $(0.05 \mathrm{mg} / \mathrm{ml})$, streptomycin $(0.05 \mathrm{mg} / \mathrm{ml})$ and neomycin $(0.1 \mathrm{mg} / \mathrm{ml})$ (all Invitrogen; Thermo Fisher Scientific, Inc.) in a humidified incubator at $37^{\circ} \mathrm{C}$ with $5 \% \mathrm{CO}_{2}$. KLN205 cells were harvested from near-confluent cultures by a brief exposure to a solution containing $0.25 \%$ trypsin and $1 \mathrm{mmol} / \mathrm{l}$ EDTA with phenol red (Invitrogen; Thermo Fisher Scientific, Inc.). Trypsinization was stopped using RPMI-1640 containing 10\% FBS. The cells were concentrated by centrifugation at $300 \mathrm{x} \mathrm{g}$ for $5 \mathrm{~min}$ at room temperature and resuspended in RPMI-1640. The cells were used for assays when they were in the logarithmic growth phase.

Chemicals. The 5-ALA was kindly donated by SBI Pharmaceuticals Co., Ltd. (Tokyo, Japan); a stock solution of $100 \mathrm{mM}$ 5-ALA in PBS was kept at $4^{\circ} \mathrm{C}$ until required. Metformin hydrochloride was purchased from Wako Pure Chemicals Industries, Ltd.; a stock solution of $100 \mathrm{mM}$ metformin hydrochloride in PBS was kept at $4^{\circ} \mathrm{C}$ until use.

$P D T$. KLN205 cells at a density of $5 \times 10^{4}$ cells $/ \mathrm{ml}$ were incubated with various 5-ALA concentrations (0, 0.6, 1.2, 2.5 and $5 \mathrm{mM}$ ) for $4 \mathrm{~h}$ at $37^{\circ} \mathrm{C}$. Following the addition of fresh medium, the cells were irradiated with a $630 \mathrm{~nm}$ laser light $(0,1,5$ and $10 \mathrm{~J} / \mathrm{cm}^{2}$ ) emitted by a diode laser (Ceralas PDT 630 Diode Laser; CeramOptec GmbH, Bonn, Germany), using a Pioneer Optics lensed fiber with a microlens delivery attachment (Pioneer Optics Co., Inc., Windsor Lock, CT, USA).

Cell viability assay. KLN205 cells were seeded into 96-well plates at a density of $1 \times 10^{4}$ cells/well, incubated overnight at $37^{\circ} \mathrm{C}$, and subsequently incubated with metformin at various concentrations $(0,0.1,1$ and $5 \mathrm{mM})$ for $24 \mathrm{~h}$. Following the addition of fresh medium, the cells were incubated at $37^{\circ} \mathrm{C}$ for $24 \mathrm{~h}$. Following this, the cells were incubated with 5-ALA at various concentrations $(0,0.6,1.2,2.5$ and $5 \mathrm{mM})$ for $4 \mathrm{~h}$ at $37^{\circ} \mathrm{C}$. Following the addition of fresh medium, the cells were irradiated with a $630 \mathrm{~nm}$ laser light $\left(0,1,5\right.$ and $\left.10 \mathrm{~J} / \mathrm{cm}^{2}\right)$. Subsequently, the cells were incubated at $37^{\circ} \mathrm{C}$ for $24 \mathrm{~h}$ in the dark. The viability of KLN205 cells was examined using the Cell Counting Kit-8 (Dojindo Molecular Technologies, Inc., Kumamoto, Japan) according to the manufacturer's instructions. The absorbance (optical density) was measured at $450 \mathrm{~nm}$ with a ChroMate ${ }^{\circledR}$ microplate reader (Awareness Technology, Inc., FL, USA). Each group included three replicates.
Fluorescent staining to examine morphological changes in KLN205 cells. To assess nuclear morphological changes, KLN205 cells a density of $1 \times 10^{4}$ cells/well were cultured on 8 wells cell culture slides (SPL Life Sciences, Pocheon, Korea). KLN205 cells were incubated with $1 \mathrm{mM}$ metformin for $24 \mathrm{~h}$ at $37^{\circ} \mathrm{C}$, washed with fresh medium, and incubated for a further $24 \mathrm{~h}$. Following incubation, cells were incubated at $37^{\circ} \mathrm{C}$ with $5 \mathrm{mM} 5$-ALA for $4 \mathrm{~h}$, washed with fresh medium, and then irradiated with a fluence of $5 \mathrm{~J} / \mathrm{cm}^{2}$. Subsequently, the cells were incubated at $37^{\circ} \mathrm{C}$ for $12 \mathrm{~h}$ in the dark. The cells were stained with $1 \mathrm{mM}$ bisbenzimidazole (Hoechst 33342) for $15 \mathrm{~min}$ at room temperature. Nuclear morphology was examined using an Olympus BX51 fluorescent microscope (Olympus Corporation, Tokyo, Japan).

Autophagy detection. To detect autophagy, KLN205 cells a density of $1 \times 10^{4}$ cells/well were cultured in 8 wells on cell culture slides. KLN205 cells were incubated with $1 \mathrm{mM}$ metformin for $24 \mathrm{~h}$ at $37^{\circ} \mathrm{C}$. Following washing with fresh medium, the cells were incubated at $37^{\circ} \mathrm{C}$ for $24 \mathrm{~h}$. They were then further incubated with $5 \mathrm{mM}$ 5-ALA for $4 \mathrm{~h}$ at $37^{\circ} \mathrm{C}$. Subsequent to washing with fresh medium, the cells were irradiated with a fluence of $5 \mathrm{~J} / \mathrm{cm}^{2}$. Subsequently, the cells were re-incubated at $37^{\circ} \mathrm{C}$ for $12 \mathrm{~h}$ in the dark. Autophagy was detected with an Autophagy/Cytotoxicity Dual Staining kit (Cayman Chemical Company, Ann Arbor, MI, USA) according to the manufacturer's instructions. The kit employs monodansylcadaverine (MDC), an autofluorescent substance incorporated into multilamellar bodies via an ion trapping mechanism and interactions with membrane lipids, as a probe for the detection of autophagic vacuoles in cultured cells. Propidium iodide (PI) was used as a marker of cell death. Images were captured using an Olympus BX51 fluorescent microscope.

Statistical analysis. Data were analyzed using the Friedman test. $\mathrm{P}<0.05$ was considered to indicate a statistically significant difference. Statistical analyses were performed using Graphpad Prism software (version 6.0; Graphpad Software, Inc., La Jolla, CA, USA).

\section{Results}

Cell survival assay. The survival of KLN205 cells following treatment with 5-ALA-PDT in combination with $0,0.1,1$ or $5 \mathrm{mM}$ metformin treatment was analyzed. In the absence of irradiation $\left(0 \mathrm{~J} / \mathrm{cm}^{2}\right.$; Fig. 1A), increasing concentrations of 5-ALA and metformin did not significantly affect cell survival. However, at a fluence of 1,5 and $10 \mathrm{~J} / \mathrm{cm}^{2}$ (Fig. 1B-D), the cytotoxic effect of 5-ALA-PDT was significantly increased in the presence of metformin. For example, at a fluence of $5 \mathrm{~J} / \mathrm{cm}^{2}, 5$-ALA-PDT treatment with $5 \mathrm{mM}$ metformin resulted in a significant increase in cytotoxicity compared with that observed with 0 and $0.1 \mathrm{mM}$ metformin $(\mathrm{P}=0.0198$ and $\mathrm{P}=0.0424$, respectively; Fig. $1 \mathrm{C}$ ). In the $10 \mathrm{~J} / \mathrm{cm}^{2}$ group, 5-ALA-PDT with $5 \mathrm{mM}$ metformin exhibited increased cytotoxicity compared to that observed with $0.1 \mathrm{mM}$ metformin $(\mathrm{P}=0.0424$; Fig. 1D).

Morphological changes in KLN205 cells. To analyze changes in cell morphology, KLN205 cells were stained with Hoechst 33342 

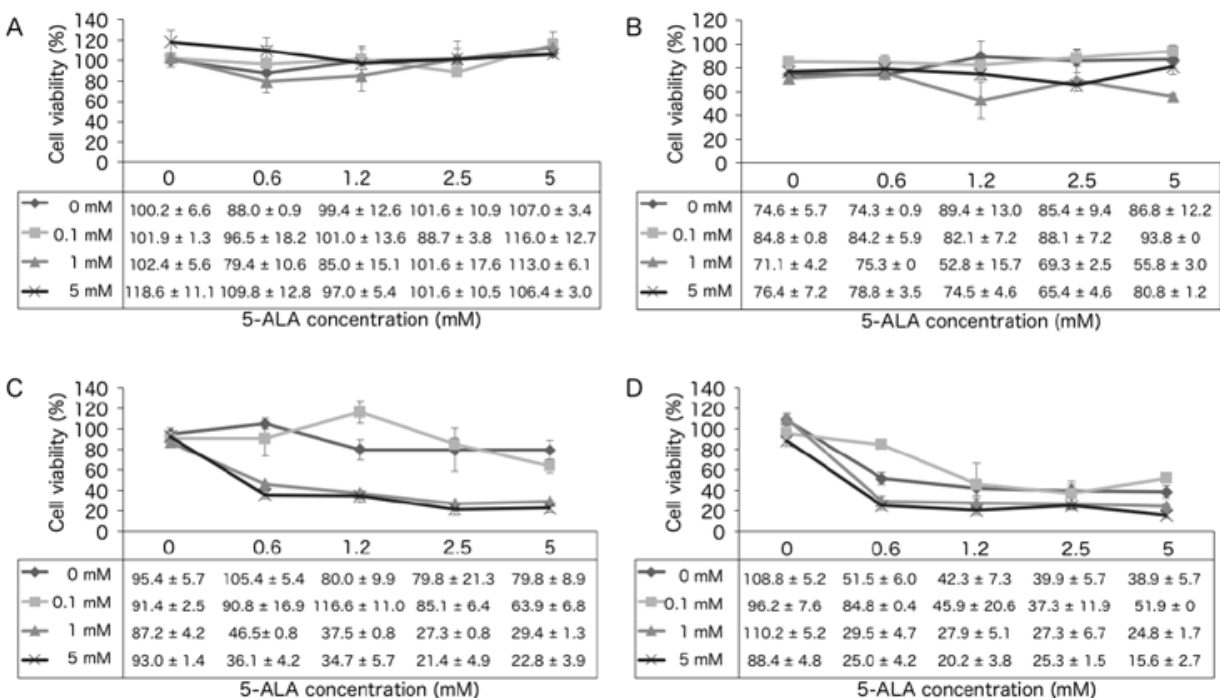

Figure 1. Cell survival assay. KLN205 cells were treated with 5-ALA-PDT at a fluence of (A) 0 , (B) 1 , (C) 5 or (D) $10 \mathrm{~J} / \mathrm{cm}^{2}$ following incubation with the indicated concentrations of 5-ALA and/or metformin. At a fluence of $1 \mathrm{~J} / \mathrm{cm}^{2}, 5$-ALA-PDT with $1 \mathrm{mM}$ metformin had a significantly increased cytotoxic effect compared with $0.1 \mathrm{mM}$ metformin $(\mathrm{P}=0.0088)$. At a fluence of $5 \mathrm{~J} / \mathrm{cm}^{2}, 5$-ALA-PDT with $5 \mathrm{mM}$ metformin had a significantly increased cytotoxic effect compared with that of 0 or $0.1 \mathrm{mM}$ metformin ( $\mathrm{P}=0.0198$ and $\mathrm{P}=0.0424$, respectively). At a fluence of $10 \mathrm{~J} / \mathrm{cm}^{2}, 5$-ALA-PDT with $5 \mathrm{mM}$ metformin had a significantly increased cytotoxic effect compared with that of $0.1 \mathrm{mM}$ metformin $(\mathrm{P}=0.0424)$. Results are presented as the mean \pm standard deviation $(\mathrm{n}=4)$. 5-ALA, 5-aminolevulinic acid; PDT, photodynamic therapy.

$12 \mathrm{~h}$ following 5-ALA-PDT treatment (5 mM 5-ALA, $5 \mathrm{~J} / \mathrm{cm}^{2}$ fluence; Fig. 2). Cells treated with 5-ALA or $1 \mathrm{mM}$ metformin alone did not exhibit any changes in nuclear chromatin or cell density (Fig. 2B and C). Cells treated with 5-ALA-PDT alone exhibited minimal condensation of nuclear chromatin and a slight decrease in cell density (Fig. 2D). However, cells treated with 5-ALA-PDT and metformin exhibited clear condensation of nuclear chromatin and a marked decrease in cell density compared with cells treated with 5-ALA-PDT alone (Fig. 2E).

Autophagy detection. To determine the effect of 5-ALA-PDT on autophagy with and without metformin, KLN205 cells were co-stained with MDC and PI $4 \mathrm{~h}$ following PDT (Fig. 3). A basal level of autophagy was detected in untreated control cells, and in cells treated with $1 \mathrm{mM}$ metformin alone, as indicated by the faint silver dot staining of autophagic vacuoles (Fig. 3A and B), although few dead cells were observed. Cells treated with 5-ALA-PDT ( $5 \mathrm{mM} 5$-ALA, $5 \mathrm{~J} / \mathrm{cm}^{2}$ fluence) with or without $1 \mathrm{mM}$ metformin treatment exhibited an increased intensity of silver dot staining and an increased number of autophagic vacuoles compared with the control group (Fig. 3C and D). PI-positive intact nuclei (necrotic cells) were observed in cells treated with 5-ALA-PDT without metformin (Fig. 3C), whereas PI-positive condensed nuclei were observed in cells treated with 5-ALA-PDT and metformin (Fig. 3D), indicating that these cells were in a late stage of apoptosis.

\section{Discussion}

Previous reports have demonstrated that metformin enhances the effect of chemotherapy and radiotherapy by promoting the AMPK-autophagy signaling pathway (15-19). Therefore, it is expected that metformin would potentiate the cytotoxicity of 5-ALA-PDT. The present study demonstrated that KN205 cells that were pre-treated with $\geq 1 \mathrm{mM}$ metformin exhibited significantly greater cytotoxicity in response to 5-ALA-PDT. This was most apparent at a PDT fluence of $5 \mathrm{~J} / \mathrm{cm}^{2}$.

A previous study demonstrated that a combination of $10 \mathrm{mM}$ metformin and $10 \mathrm{nM}$ paclitaxel was more effective at inhibiting cell growth compared with paclitaxel alone, due to an increase in AMPK activation and the subsequent reduction of signaling through the mTOR pathway (16). It has also been demonstrated that 1 and $5 \mathrm{mM}$ metformin causes a significant increase in radiosensitization at a radiation concentration $>3$ Gy (19). The combination of metformin and irradiation was more efficient than radiation or metformin alone at inactivating AMPK, and inactivating MTOR and its targets ribosomal protein S6 kinase $\beta-1$ and eukaryotic translation initiation factor 4E-binding protein 1 (19). The combination of 5-ALA-PDT and metformin used in the present study may also activate AMPK and inactivate mTOR to initiate cell death.

PDT induces cell death via apoptosis, autophagy and necrosis. In KLN205 cells treated with 5-ALA-PDT and metformin, marked condensation of nuclear chromatin and a decrease in cell density were observed at $12 \mathrm{~h}$ following PDT, compared with cells treated with 5-ALA-PDT alone. The morphological changes observed indicate that a higher amount of apoptotic events occurred in cells treated with 5-ALA-PDT and metformin compared with cells treated with 5-ALA-PDT or metformin alone, suggesting that 5-ALA-PDT in combination with metformin is more effective than either monotherapy.

Increased numbers of autophagosomes were observed in cells treated with 5-ALA-PDT with and without metformin compared with untreated control cells (Fig. 3). However, treatment with 5-ALA-PDT and metformin did not increase the number of autophagosomes compared with 5-ALA-PDT treatment alone. A previous study demonstrated that increased numbers of MDC-positive autophagosomes were found as early as $2 \mathrm{~h}$ following 5-ALA-PDT administration, whereas little 

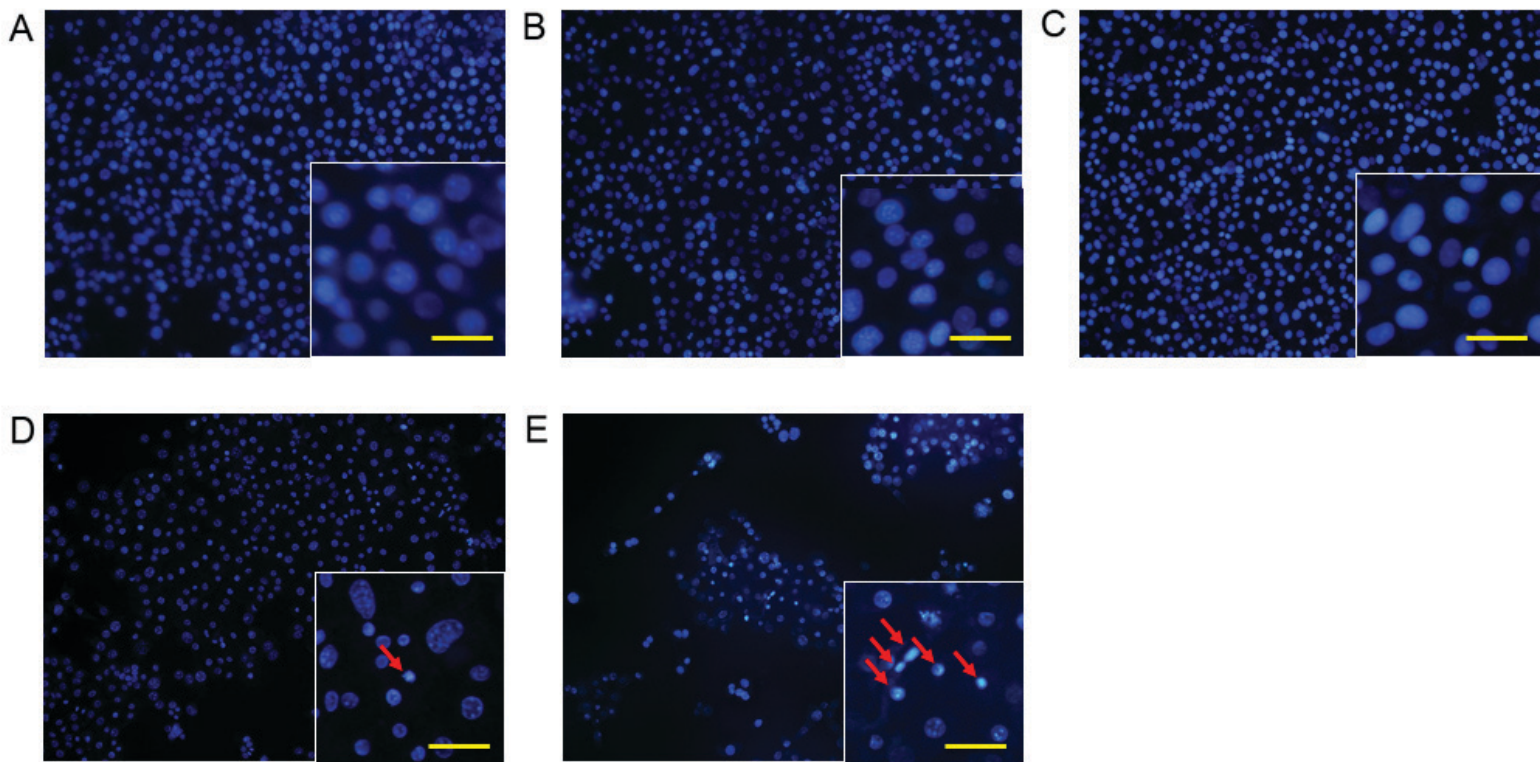

Figure 2. Representative photomicrographs of Hoechst 33342-stained KLN205 cells of the (A) untreated control group, (B) 5-ALA alone group, (C) metformin alone group, (D) 5-ALA-PDT treatment group $\left(5 \mathrm{~J} / \mathrm{cm}^{2}\right)$ and (E) 5-ALA-PDT $\left(5 \mathrm{~J} / \mathrm{cm}^{2}\right)$ with metformin group (Lower magnification, $\mathrm{x} 40$ ). The control, 5-ALA alone and metformin groups did not exhibit condensation of nuclear chromatin or a decrease in cell density. The ALA-PDT treatment group exhibited minimal condensation of nuclear chromatin and a slight decrease in cell density. The 5-ALA-PDT with metformin group exhibited markedly increased condensation of nuclear chromatin and a marked decrease in cell density compared to the group treated with 5-ALA-PDT alone. Insets show a close-up view of tumor cells (scale bar, $20 \mu \mathrm{m}$ ). Arrows indicate nuclear chromatin condensation. 5-ALA, 5-aminolevulinic acid; PDT, photodynamic therapy.

A

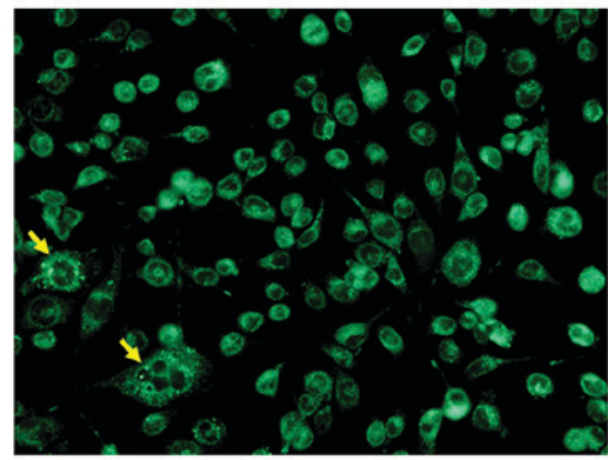

C

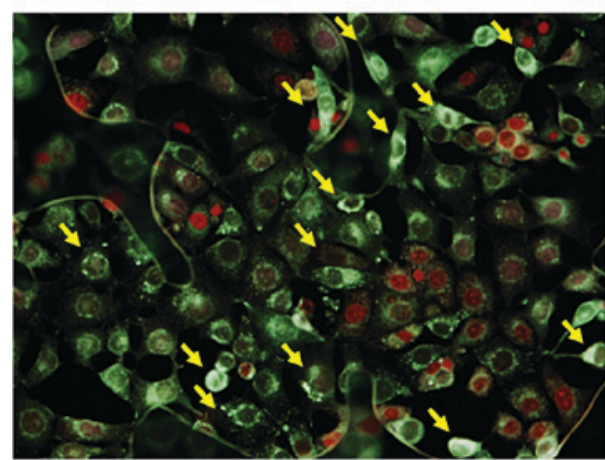

B
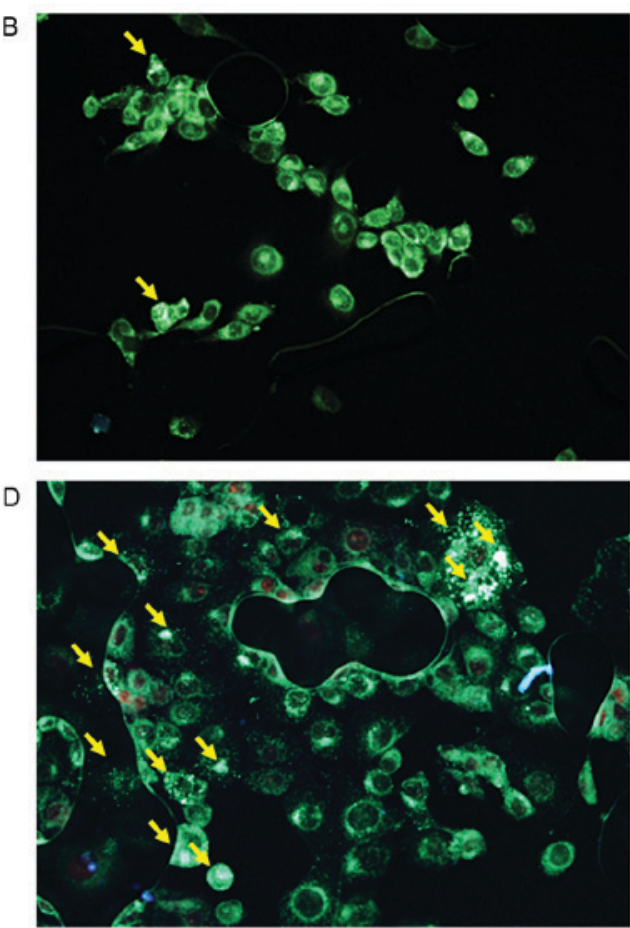

Figure 3. Autophagy detection using monodansylcadaverine and propidium iodide co-staining 4 h following photodynamic therapy (PDT) in the (A) untreated control group, (B) metformin alone group, (C) 5-ALA-PDT (5 J/ $\left.\mathrm{cm}^{2}\right)$ group and (D) 5-ALA-PDT (5 J/cm $\left.{ }^{2}\right)$ with metformin group. The untreated control group exhibited few autophagosomes. The 5-ALA-PDT group and the 5-ALA-PDT with metformin group exhibited increased numbers of autophagosomes. Magnification, x200. Yellow arrows indicate autophagosomes. 5-ALA, 5-aminolevulinic acid; PDT, photodynamic therapy.

MDC incorporation was observed in control cells (8). Additionally, 5-ALA-PDT-induced autophagic cell death was mediated by AMPK. The results of the present study suggest that the combination of 5-ALA-PDT and metformin predominantly induces apoptosis, but also autophagy, via AMPK activation.
In conclusion, the present study is the first to demonstrate, to the best of our knowledge, that metformin effectively potentiates the efficacy of 5-ALA-PDT. Further studies are required to demonstrate the molecular mechanism underlying the cell death induced by the combination of 5-ALA-PDT and metformin. 


\section{Acknowledgements}

The authors would like to thank Editage (www.editage.jp) for their English language editing.

\section{References}

1. Sharman WM, Allen CM and van Lier JE: Photodynamic therapeutics: Basic principles and clinical applications. Drug Discov Today 4: 507-517, 1999.

2. Agostinis P, Berg K, Cengel KA, Foster TH, Girotti AW, Gollnick SO, Hahn SM, Hamblin MR, Juzeniene A, Kessel D, et al: Photodynamic therapy of cancer: An update. CA Cancer J Clin 61: 250-281, 2011.

3. Moore JV, West CM and Whitehurst C: The biology of photodynamic therapy. Phys Med Biol 42: 913-935, 1997.

4. Wachowska M, Muchowicz A, Firczuk M, Gabrysiak M, Winiarska M, Wańczyk M, Bojarczuk K and Golab J: Aminolevulinic acid (ALA) as a prodrug in photodynamic therapy of cancer. Molecules 16: 4140-4164, 2011.

5. Ishizuka M, Abe F, Sano Y, Takahashi K, Inoue K, Nakajima M, Kohda T, Komatsu N, Ogura S and Tanaka T: Novel development of 5-aminolevurinic acid (ALA) in cancer diagnoses and therapy. Int Immunopharmacol 11: 358-365, 2011.

6. Nokes B, Apel M, Jones C, Brown G and Lang JE: Aminolevulinic acid (ALA): Photodynamic detection and potential therapeutic applications. J Surg Res 181: 262-271, 2013.

7. Amo T, Kawanishi N, Uchida M, Fujita H, Oyanagi E, Utsumi T, Ogino T, Inoue K, Shuin T, Utsumi K and Sasaki J: Mechanism of cell death by 5-aminolevulinic acid-based photodynamic action and its enhancement by ferrochelatase inhibitors in human histiocytic lymphoma cell line U937. Cell Biochem Funct 27: 503-515, 2009.

8. Ji HT, Chien LT, Lin YH, Chien HF and Chen CT: 5-ALA mediated photodynamic therapy induces autophagic cell death via AMP-activated protein kinase. Mol Cancer Ther 9: 91, 2010.

9. Ben Sahra I, Le Marchand-Brustel Y, Tanti JF and Bost F: Metformin in cancer therapy: A new perspective for an old antidiabetic drug? Mol Cancer Ther 9: 1092-1099, 2010.
10. Del Barco S, Vazquez-Martin A, Cufí S, Oliveras-Ferraros C, Bosch-Barrera J, Joven J, Martin-Castillo B and Menendez JA: Metformin: Multi-faceted protection against cancer. Oncotarget 2: 896-917, 2011.

11. Dowling RJ,Zakikhani M, Fantus IG, Pollak M and Sonenberg N: Metformin inhibits mammalian target of rapamycin-dependent translation initiation in breast cancer cells. Cancer Res 67: 10804-10812, 2007.

12. Ben Sahra I, Laurent K, Loubat A, Giorgetti-Peraldi S, Colosetti P, Auberger P, Tanti JF, Le Marchand-Brustel Y and Bost F: The antidiabetic drug metformin exerts an antitumoral effect in vitro and in vivo through a decrease of cyclin D1 level. Oncogene 27: 3576-3586, 2008 .

13. Cantrell LA, Zhou C, Mendivil A, Malloy KM, Gehrig PA and Bae-Jump VL: Metformin is a potent inhibitor of endometrial cancer cell proliferation-implications for a novel treatment strategy. Gynecol Oncol 116: 92-98, 2010.

14. Dowling RJ, Goodwin PJ and Stambolic V: Understanding the benefit of metformin use in cancer treatment. BMC Med 9: 33, 2011.

15. Rattan R, Graham RP, Maguire JL, Giri S and Shridhar V: Metformin suppresses ovarian cancer growth and metastasis with enhancement of cisplatin cytotoxicity in vivo. Neoplasia 13: 483-491, 2011.

16. Rocha GZ, Dias MM, Ropelle ER, Osório-Costa F, Rossato FA, Vercesi AE, Saad MJ and Carvalheira JB: Metformin amplifies chemotherapy-induced AMPK activation and antitumoral growth. Clin Cancer Res 17: 3993-4005. 2011.

17. Lin CC, Yeh HH, Huang WL, Yan JJ,Lai WW, Su WP, Chen HH and Su WC: Metformin enhances cisplatin cytotoxicity by suppressing signal transducer and activator of transcription-3 activity independently of the liver kinase B1-AMP-activated protein kinase pathway. Am J Respir Cell Mol Biol 49: 241-250, 2013.

18. Lin YC, Wu MH, Wei TT, Lin YC, Huang WC, Huang LY, Lin YT and Chen CC: Metformin sensitizes anticancer effect of dasatinib in head and neck squamous cell carcinoma cells through AMPK-dependent ER stress. Oncotarget 5: 298-308, 2014.

19. Song CW, Lee H, Dings RP, Williams B, Powers J, Santos TD, Choi BH and Park HJ: Metformin kills and radiosensitizes cancer cells and preferentially kills cancer stem cells. Sci Rep 2: $362,2012$. 